\title{
超高強度コンクリート供試体の載荷面の平面度と圧縮強度の関係 に関する基礎的研究 \\ BASIC STUDY ON RELATION BETWEEN FLATNESS OF END OF HIGH STRENGTH CONCRETE SPECIMEN AND COMPRESSIVE STRENGTH
}

\author{
小山善行*, 早川光敬**, 陣内 浩***, 中村光男 ${ }^{* * * *}$ \\ Yoshiyuki KOYAMA, Mitutaka HAYAKAWA, Hiroshi JINNAI \\ and Mitsuo NAKAMURA
}

\begin{abstract}
In this research, the relation between the flatness of the end of the high strength concrete specimen and its compressive strength was examined. The results of the examination are shown as follows. (1) The flatness of the end of the specimen can be evaluated by measuring 17 points with a device shown in JIS A 5308. (2) Flatness of the end of the specimen will change with the time passing. Therefore, specimens should be ground just before the strength test. (3) Every flatness of the end of the grounded specimen was within the limits regulated in JIS A 1132. (4) In this experiment, compressive strength decreased as the roughness of the end of the specimen increased. (5) In this experiment, the influence of the flatness on the strength reduction rate increased with the rise of the compressive strength level.
\end{abstract}

Keywords Specimen, Flatness measurement, Compressive Strength, High Strength Concrete 供試体, 平面度測定, 圧縮強度, 超高強度コンクリート

1. はじめに

近年, コンクリート構造物の高層化, 大型化に伴い, コンクリー トの高強度化が進んでいる。このような高強度コンクリートでは, 圧縮強度試験に用いる供試体の載荷面の成形もしくは整形方法が, 圧縮強度試験結果に大きく影響することが既往の研究1)-3)によって 報告されている。

圧縮強度試験の精度を確保する上では, 供試体の載荷面の平面度 が重要である事は言うまでも無く，研究成果も多数報告4）１0）され ている。しかし，供試体の載荷面の平面度と圧縮強度の関連性につ いて詳細に検討された多くの研究は, 圧縮強度 $30 \mathrm{~N} / \mathrm{mm}^{2}$ 以下の一 般的な強度領域でのものであり, 近年普及している超高強度領域に 関しては, データの蓄積が望まれている。

一方, 高強度コンクリート供試体の試験方法に関連する技術動向 としては，1997 年に JIS A 5308「レディーミクストコンクリート」 に取り込まれた軽量型枠の普及や, 供試体端面処理用の研磨機の普 及などがある。これらが普及した時期は，多くの研究者が供試体の 平面度と圧縮強度の関係を検討していた時期よりも年代的に新しく， 軽量型枠を用いて作られた高強度コンクリート供試体の載荷面の平
面度がどの程度の成形精度なのか，また研磨機によって整形された 供試体の載荷面の平面度がどの程度の整形精度なのかはあまり明確 ではない。しかしながら, 昨今では様々な高強度コンクリートの強 度管理手法が提案されており，建築工事で使用される簡易断熱養生 供試体11)の作製などでは, 軽量型枠を利用するのが一般的になって いる。また，キャッピングに用いる材料の強度などの問題から，超 高強度コンクリートで作製された供試体の載荷面の端面処理は研磨 で実施されることが多い。このような背景から考えると，前述した 軽量型枠で成形された供試体の載荷面の平面度や, 研磨後の平面度, また養生期間中の経過時間に伴う平面度の変化などを調査した上で, 超高強度コンクリート供試体の載荷面の平面度と圧縮強度試験の関 係について整理しておくことには意味があると考えられる。

そこで本研究では, 圧縮強度 $100 \mathrm{~N} / \mathrm{mm}^{2}$ を超える高強度コンクリ 一ト供試体の載荷面の処理作業における留意点を明確にすることを 目的とし，供試体の載荷面の平面度と圧縮強度試験の関係について 一連の実験を行った。

\footnotetext{
* 東京工芸大学大学院工学研究科建築学専攻 (東京検査(株) 代表取締役社長)

** 東京工芸大学工学部建築学科 教授 ·博士 (工学)

*** 大成建設(株技術センター 主任研究員・博士 (工学)

**** 東京検査(株)建材研究所 所長
}

Graduate Student, Graduate School of Eng., Tokyo Polytechnic Univ. (Tokyo Kensa Co., Ltd., President)

Prof., Dept. of Architecture, Faculty of Eng., Tokyo Polytechnic Univ., Dr. Eng.

Senior Research Engineer, Technology Center, Taisei Corp., Ph. D.

Director, Tokyo Kensa Co., Ltd., Construction Materials Laboratory 


\section{2. 供試体端面に関する基本検討}

ここでは, 平面度と圧縮強度試験の関係についての実験に先立ち, 供試体の載荷面の平面度測定方法, 測定時期の妥当性などを検討寸 るとともに，JIS A 5308「レディーミクストコンクリート」附属書 E （規定）軽量型枠の適合品として実際に使われているぶりき製の軽 量型枠およびプラスチック製の軽量型枠で成形された供試体の端面 精度, 研磨した供試体の端面精度などを調査することとした。

\section{1 平面度の測定方法に関する基本検討}

一般に, 圧縮強度試験用円柱供試体の端面精度を評価する指標と しては，JIS A 1132「コンクリート強度試験用供試体の作り方」に示 される直径の $0.05 \%$ 以内が用いられている。また，この精度を測定 寸る手法としては，JIS A 5308 の附属書 5 に示される平面度測定装 置が用いられていることが多い。そこで本研究では，JIS に示され る平面度測定装置を用いて, 供試体の平面度を測定することとした。 使用した平面度測定装置を写真 1 に示す。JIS A 5308 における供試 体端面の平面度とは, 直交する 2 本の直線を測線として, それぞれ について測線上の両端部を結ぶ線と中心部の高低差を求め, 両者を 平均した值と寸ることになっている。しかし, 過去の研究では, JIS A 5308 よりも多くの測定点を用いて平面度を評価したものが多く, ぞの程度の測定点が妥当なのかは必ずしも明確ではない。そこで, ここでは, 何点以上の測定点で供試体の平面度を安定的に評価でき るのかを検討した。なお，ここでの平面度の定義は，JIS B 7513「精 密定盤」に示される「使用面を幾何学的に正しい平行二平面で挟んだ とき, 平行二平面の間隔が最小となる間隔の寸法」とした。

実験では，平面度測定装置を用いて，研磨を行った $\Phi 100 \times 200 \mathrm{~mm}$ 円柱供試体の端面を測定することとした。測定点は, 図 1 に示す 17 点を基本とした。測定では, 測定点(1)を中心に, 測定点(2)から(17)を 15 度, 22.5 度, 30 度と回転させた計 65 点 $(17$ 点+16 点 +16 点+16 点）の端面高さを測定した。平面度測定装置の校正では, 真平面と いう校正用具が入手できなかったため，ここではキャッピング用ガ ラス板の平面度測定值が $0.00 \mathrm{~mm}$ となることをもとに, 平面度測定装 置の精度確認を行っている。また, 面内のある点の高さを測定する という試験の特性から, 試験誤差が結果に与える影響は大きいと考 えられた。そこで, 測定対象とする面数は 100 面とし, 試験誤差が 全体的な結果の傾向に与える影響を多数の面の測定によって抑制す ることとした。

測定点数と平面度測定值の関係を図 2 に示寸。図中, 平均として いるのは測定面数 100 面の平均平面度測定値, 最大および最小とし ているのは, 各測定点数での測定面数 100 面の中の最大平面度測定 值と最小平面度測定值である。つまり, 100 面分の平面度測定值は, ○と $\triangle$ 間に縦に分布していることになる。図 2 からわかるように, 平面度測定值は, 測定点数が増加寸るにつれて大きくなった。傾向 的には, 平面度測定值は表 1 に示寸 17 点までは点数の増加とともに 急激に大きくなった。測定点が 17 点を超えると, 点数を 2 倍, 3 倍 と増加させても, 平面度測定值は極端に大きくなることはなかった。

測定面数 100 面の平面度測定值を測定点数ごとに分類したヒスト グラムを図 3 に示す。これより, 今回のような測定点の配置で考え た場合には, 17 点程度の平面測定を行えば, 概ねとの 4 倍近い点数 で平面測定をした結果に近い結果が得られることがわかる。

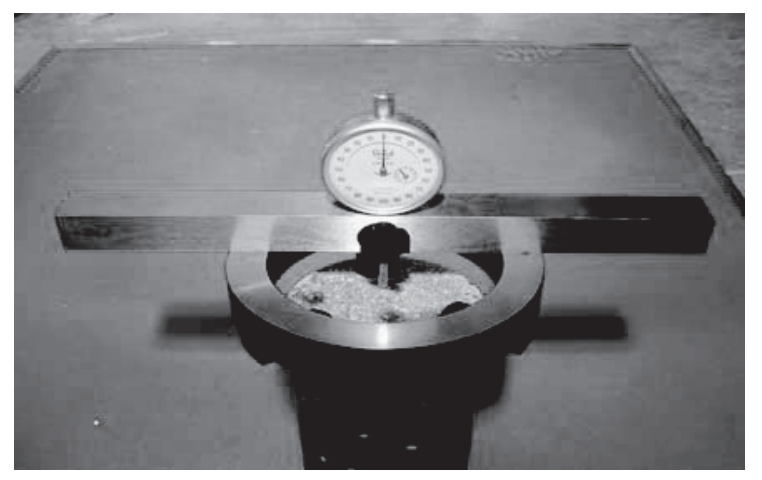

写真 1 使用した平面度測定装置

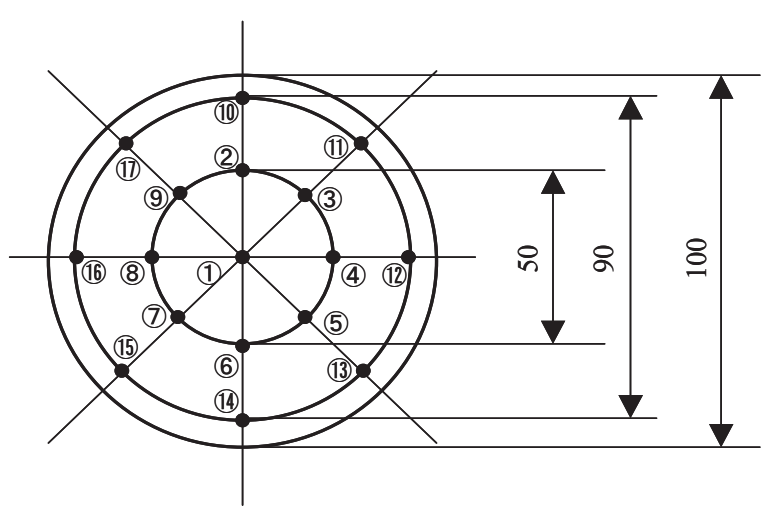

図 1 測定点数と計測

表 1 平面度算出用測定点の設定

\begin{tabular}{|c|c|}
\hline $\begin{array}{l}\text { 設定 } \\
\text { 点数 } \\
\end{array}$ & 測定点 \\
\hline 5 & (1) (10)(12) (14)(16) \\
\hline 9 & (1) (2) (4) (6) (8) (10) (12) (14)(16) \\
\hline 13 & (1) (2) (4) (6) (8)(10)(11)(12)(13)(14)(15)(16)(17) \\
\hline 17 & (1) (2) (3)(4)(5)(6) (7) 8) (9)(10)(11)(12)(13)(14)(15)(16)(17) \\
\hline 25 & 上記 17 点+15 度回転の (2) (9) \\
\hline 33 & 上記 17 点+15 度回転の (2) (17) \\
\hline 41 & 上記 33 点+22. 5 度回転の (2) (9) \\
\hline 49 & 上記 33 点+22. 5 度回転の (2) (17) \\
\hline 57 & 上記 49 点+30 度回転の (2) (9) \\
\hline 65 & 上記 49 点+30 度回転の (2) (17) \\
\hline
\end{tabular}

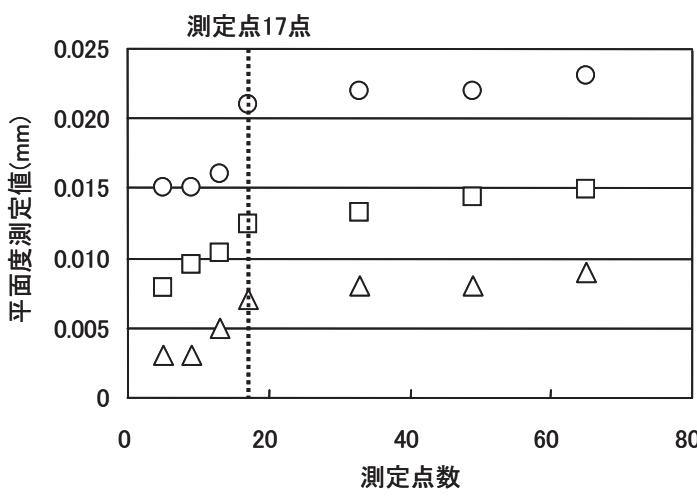

図 2 測定点数と平面度測定值の関係 

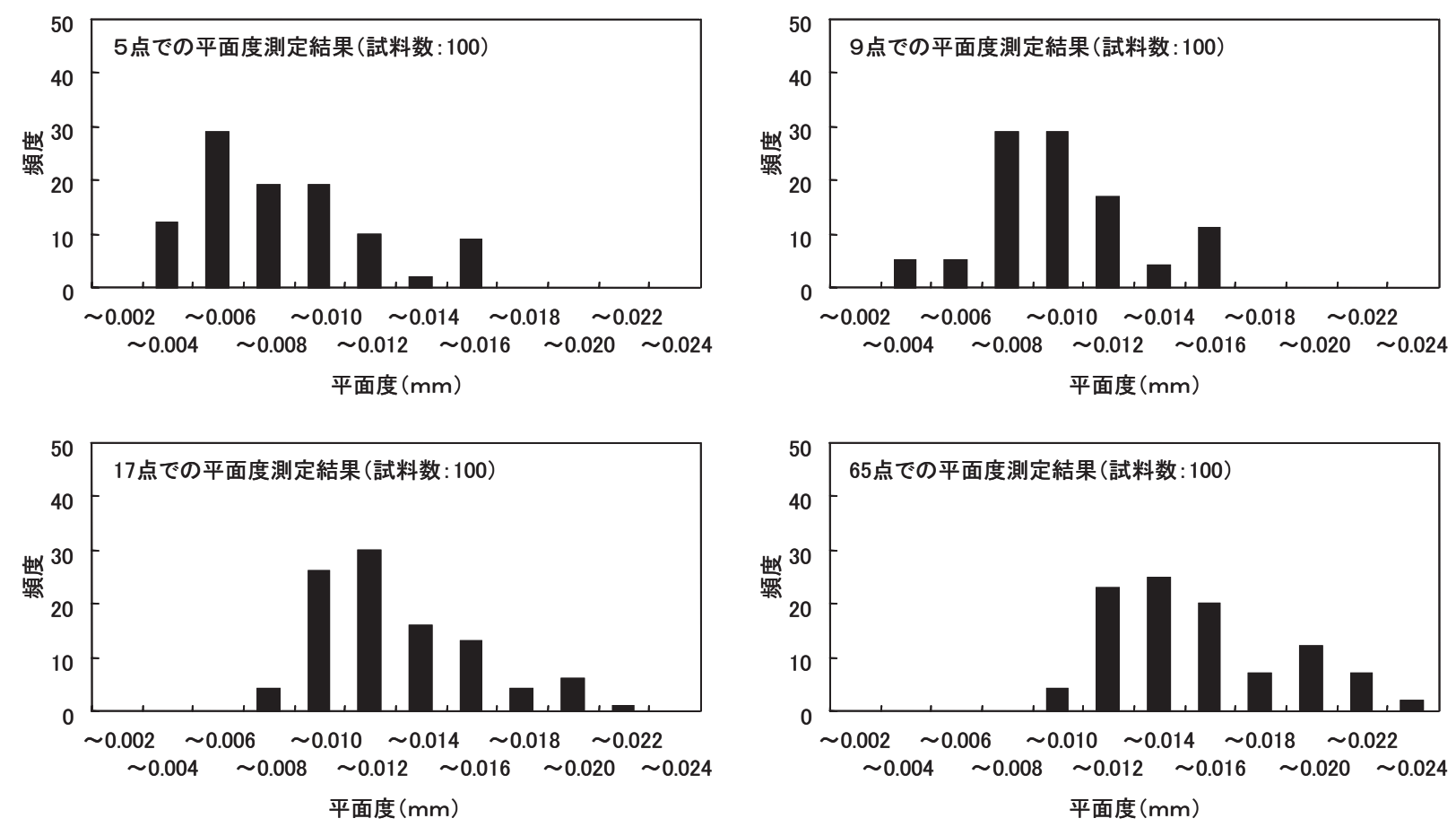

図 3 測定面数 100 面の平面度測定結果の分布

表 2 使用材料

\begin{tabular}{|c|c|c|c|}
\hline 種類 & 記号 & 名称 & 備考 \\
\hline \multirow{2}{*}{ 結合材 } & B1 & 高強度用結合材* & 密度 $2.99 \mathrm{~g} / \mathrm{cm}^{3}$ \\
\hline & B2 & 普通ポルトランドセメト & 密度 $3.16 \mathrm{~g} / \mathrm{cm}^{3}$ \\
\hline \multirow{4}{*}{ 細骨材 } & $\mathrm{S} 1$ & 安山岩系砕砂 & $\begin{array}{l}\text { 表乾密度 } 2.60 \mathrm{~g} / \mathrm{cm}^{3} \\
\text { 吸水率 } 3.18 \%\end{array}$ \\
\hline & $\mathrm{S} 2$ & 天然砂 & $\begin{array}{l}\text { 表乾密度 } 2.64 \mathrm{~g} / \mathrm{cm}^{3} \\
\text { 吸水率 } 2.36 \%\end{array}$ \\
\hline & $\mathrm{S} 3$ & 石灰岩系砕砂 & $\begin{array}{l}\text { 表乾密度 } 2.65 \mathrm{~g} / \mathrm{cm}^{3} \\
\text { 吸水率 } 1.33 \%\end{array}$ \\
\hline & $\mathrm{S} 4$ & 天然砂 & $\begin{array}{l}\text { 表乾密度 } 2.58 \mathrm{~g} / \mathrm{cm}^{3} \\
\text { 吸水率 } 2.29 \%\end{array}$ \\
\hline \multirow{3}{*}{ 粗骨材 } & G1 & 安山岩系砕石 & $\begin{array}{l}\text { 表乾密度 } 2.62 \mathrm{~g} / \mathrm{cm}^{3} \\
\text { 吸水率 } 2.36 \%\end{array}$ \\
\hline & G2 & 硬質砂岩系砕石 & $\begin{array}{l}\text { 表乾密度 } 2.66 \mathrm{~g} / \mathrm{cm}^{3} \\
\text { 吸水率 } 0.65 \%\end{array}$ \\
\hline & G3 & 石灰岩系砕石 & $\begin{array}{l}\text { 表乾密度 } 2.70 \mathrm{~g} / \mathrm{cm}^{3} \\
\text { 吸水率 } 0.63 \%\end{array}$ \\
\hline
\end{tabular}

*普通ポルトランドセメト：スラグせっこう系混和材 $12 ） ：$ 汌カューム＝7：2:1

以上の結果より, 本研究では多数の供試体の載荷面の平面度を測 定する現実的な測定点数として, 図 1 に示寸 17 点によって求めた 平面度を供試体の載荷面の平面度とみなし, これ以降の研究を進め ることとした。

\section{2 脱型後の経過時間が平面度に与える影響の検討}

JIS A 1132「コンクリート強度試験用供試体の作り方」では, 検定 された型朹を用いる場合には, 供試体の載荷面の平面度測定を省略 して良いこととなっている。これは, 脱型から圧縮強度試験までの 供試体の載荷面の平面度がほぼ同等とみなせるという判断によるも
表 3 使用材料の組合せ

\begin{tabular}{c|c|c|c|c}
\hline 調合名 & $\begin{array}{c}\text { W/B } \\
(\%)\end{array}$ & 結合材 & 細骨材 & 粗骨材 \\
\hline \hline $\mathrm{C} 1$ & 15 & $\mathrm{~B} 1$ & $\mathrm{~S} 1$ & $\mathrm{G} 3$ \\
\hline $\mathrm{C} 2$ & 20 & $\mathrm{~B} 1$ & $\mathrm{~S} 1$ & $\mathrm{G} 3$ \\
\hline $\mathrm{C} 3$ & 30 & $\mathrm{~B} 2$ & $\mathrm{~S} 2$ & $\mathrm{G} 3$ \\
\hline $\mathrm{C} 4$ & 45 & $\mathrm{~B} 2$ & $\mathrm{~S} 2$ & $\mathrm{G} 3$ \\
\hline $\mathrm{C} 5$ & 55 & $\mathrm{~B} 3$ & $\mathrm{~S} 3: \mathrm{S} 4=4: 6$ & $\mathrm{G} 2: \mathrm{G} 3=5: 5$ \\
\hline
\end{tabular}

表 4 コンクリートの調合

\begin{tabular}{c|c|c|c|c|c}
\hline \multirow{2}{*}{ 調合名 } & \multirow{2}{*}{$\begin{array}{l}\text { W/B } \\
(\%)\end{array}$} & \multicolumn{4}{|c}{ 単位量 $\left(\mathrm{kg} / \mathrm{m}^{3}\right)$} \\
\cline { 3 - 6 } & & 結合材 & 水 & 細骨材 & 粗骨材 \\
\hline \hline $\mathrm{C} 1$ & 15 & 1000 & 150 & 497 & 811 \\
\hline $\mathrm{C} 2$ & 20 & 750 & 150 & 712 & 811 \\
\hline $\mathrm{C} 3$ & 30 & 583 & 175 & 702 & 905 \\
\hline $\mathrm{C} 4$ & 45 & 389 & 175 & 863 & 905 \\
\hline $\mathrm{C} 5$ & 55 & 326 & 179 & 820 & 966 \\
\hline
\end{tabular}

のと考えられる。しかしながら，高強度コンクリートの管理では， 従来の材齢 28 日での管理よりも長い材齢を設定するケースも多く, JIS A 1132 の概念をそのまま用いて良いのかについては疑問が残る。 そこで, ここでは研磨後の経過時間が平面度測定值の結果に与える 影響について検討した。

実務では, 脱型後の供試体を水中養生槽に数個積み重ねて養生し ていることが多い。そこで，実験では水結合材比の異なる 5 種類の コンクリートで円柱供試体を作製し， $20^{\circ} \mathrm{C}$ 水中養生槽内での平面度 の経時変化を測定することとした。使用材料および各調合での材料 
の組合せを表 2 および表 3 に, 調合を表 4 に示す。使用材料の組合 せや調合は, 実際に使われている調合例をもとに定めている。測定 では, 平面度の経時変化をとらえ易いように, 材齢 7 日で測定面と する供試体の打込み側の載荷面（以下, 研磨面）を研磨した。次に, 平面度測定を行う 17 点をマーキングし, 2.1 で定めた測定方法に よって平面度が JIS A 1132 の許容範囲（0.05m) に入っていること を確認した上で, $20^{\circ} \mathrm{C}$ 水中養生槽内に積み重社た。供試体数は各調 合とも 3 個とした。実務では供試体の載荷面は露出させたままとな るが，測定面に炭酸カルシウムなどが付着すると測定值の位置付け が曖昧となるため, 供試体の測定面はラップで覆うこととした。し たがって, 供試体は $20^{\circ} \mathrm{C}$ 水中で供試体側面からのみ吸水することが できる状態で経過観察をしたこととなる。平面度の測定は, 基調と なる材齢 7 日から開始し, 打込久からの材齢で 14 日, 28 日, 91 日 および 6 ケ月に行った。

各調合の平面度の経時変化を図 4 に示す。図 4 の縦軸は, 供試体 ごとに各材齢における平面度と材齢 7 日の平面度の差を算出し, 同 条件の供試体（3 個）について平均したものである。図4 からわか るように, 供試体の載荷面の平面度は, 材齢が経過すると大きくな る傾向にあり, 研磨直後と同じ状態を保持できる訳ではない。つま り，供試体の載荷面の整形時期は，圧縮強度試験の試験材齢とあま り離れていないことが望ましい。なお，今回の実験では調合の影響 はあまり明確とはならなかったが, 余裕をみて考えれば, JIS A 1132 の $0.05 \mathrm{~mm}$ という許容範囲に対し, 材齢 6 ケ月までに平面度が最大で $0.015 \mathrm{~mm}$ 程度大きくなる可能性もある。したがって, 検定された型 枠を用いて供試体の平面度測定を省略する場合や, 載荷面の研磨か ら圧縮強度試験までの期間が長い場合には, 型枠底面側の載荷面 (以 下，供試体底面）や研磨した載荷面の平面度が JIS A 1132 の許容範 囲 $(0.05 \mathrm{~mm})$ を十分に下回っていることを確認するのが良い。

\section{3 供試体の載荷面の平面度}

ここでは, ぶりき製の軽量型枠およびプラスチック製の軽量型枠 で作製された供試体底面, および打込み側載荷面を研磨して成型を 行った供試体の載荷面の平面度がどの程度の精度であるのかを検討 することとした。軽量型枠で作製された供試体底面の平面度測定に は，ぶりき製の軽量型枠 A で作製した $\Phi 100 \times 200 \mathrm{~mm}$ 供試体 119 個, およびプラスチック製の軽量型枠 B で作製した $\Phi 100 \times 200 \mathrm{~mm}$ 供試体 256 個を使用した。様々な調合の供試体を用いたため調合表などは 割愛するが，いずれの供試体の作製にもスランプフロー $600 \mathrm{~mm}$ 以上 の高流動コンクリートを使用し, 供試体底面の載荷面に気泡などが 残らないようにしている。また, 研磨を行った供試体研磨面の平面 度測定には，筆者らが他の実験などに用いた供試体のデータを収集 し，全 127 面のデータについて分析した。

軽量型枠で作製した供試体底面の平面度測定結果を図 5 に示す。 今回の測定結果では, いずれの軽量型枠で作製した供試体底面の平 面度でも, JIS A 1132 の許容範囲 $(0.05 \mathrm{~mm})$ を超えるケースが多く, 軽量型枠で作製した供試体底面が JIS A 1132 に規定される平面度を 満たすケースは, 約 3 面に 1 面であった。JIS A 5308 附属書 Eに適 合する軽量型枠で作製した供試体底面が JIS A 1132 を満たせなかっ た理由としては, 経時によるコンクリートの収縮によって平面保持 が損なわれた可能性が考えられる。この点は, 鋼製型枠であっても 無視できない問題と考える。特に, 長期材齢管理となるコンクリー

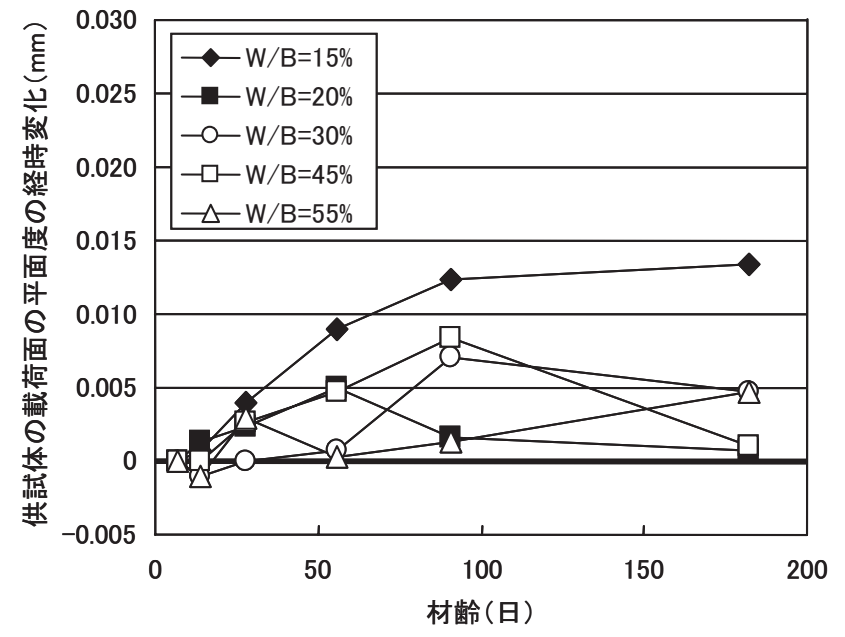

図 4 供試体載荷面（研磨面）の平面度の経時変化
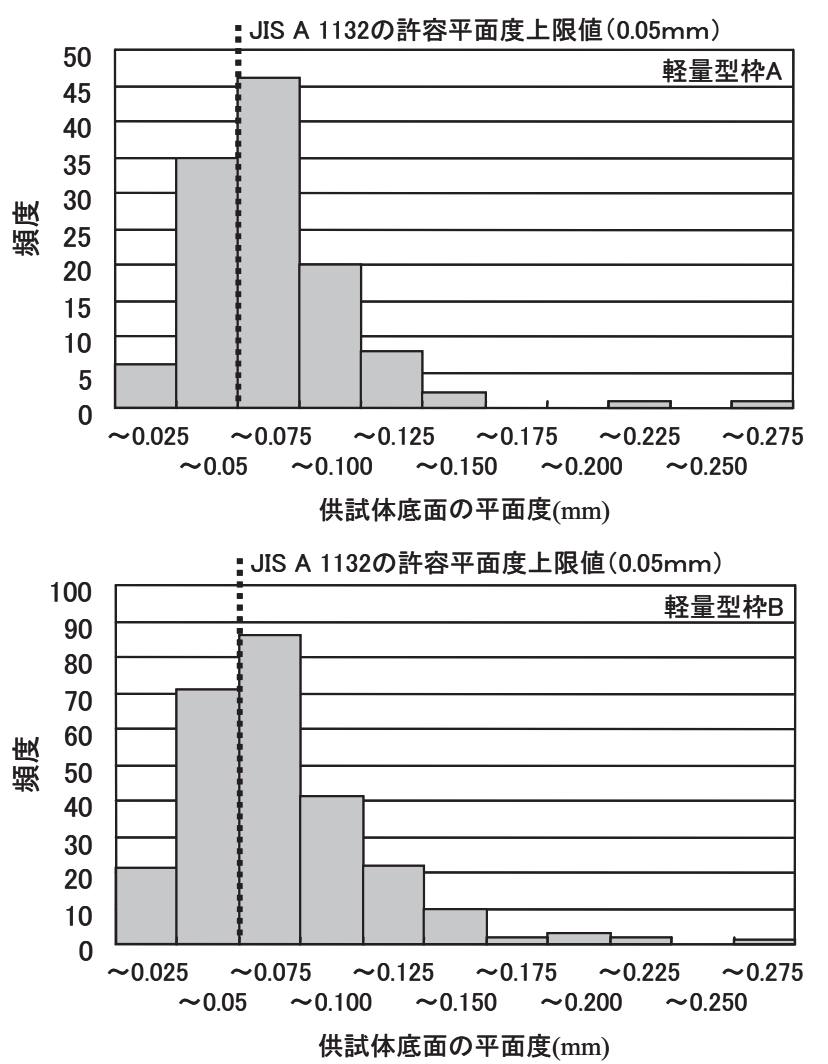

図 5 軽量型枠で作製した供試体底面の平面度測定結果

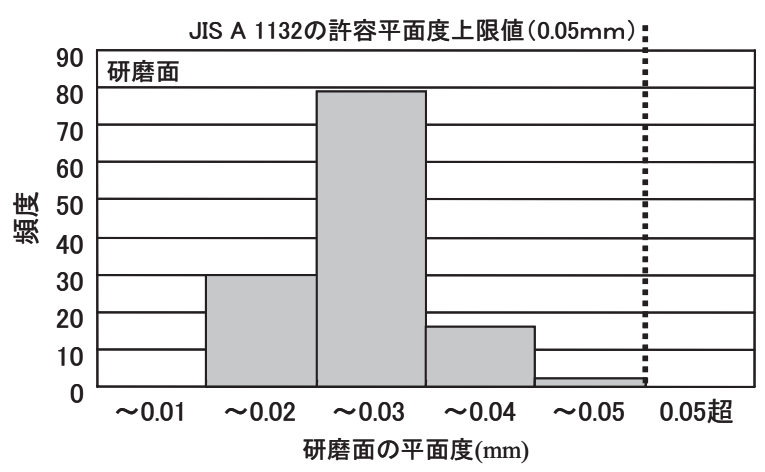

図 6 研磨面の平面度測定結果 
卜供試体では, 圧縮強度試験前に供試体底面の載荷面も研磨などで 平面度を向上させることが望ましいと考える。

載荷面を研磨した後に平面度を測定した結果を図 6 に示す。使用 した研磨機はダイヤモンド砥石による注水研磨機で, 電動振子式・ 扇型運動による直角度研磨方式である。図 6 からわかるように, 研 磨後の供試体端面で JIS A 1132 の許容範囲を超えるものは なかった。したがって, 今回のような方法で供試体端面を研磨処理 寸れば，JIS A 1132 を満たすことができると思われた。

\section{3. 載荷面の平面度が圧縮強度試験結果に与える影響の検討}

ここまでの基本検討の結果を踏まえ, 圧縮強度 $100 \mathrm{~N} / \mathrm{mm}^{2}$ を超える 5 種類の高強度コンクリートで作製した円柱供試体の載荷面の平面 度が圧縮強度試験結果に与える影響を検討することとした。筆者ら は，文献1)においてこれと似た実験を行っているが，同条件の供試 体の個数が少なく，傾向の把握が難しかったことを報告している。 そこで本実験では，均質に練混ぜたコンクリートで 1 調合あたり $\Phi$ $100 \times 200 \mathrm{~mm}$ 供試体を 48 個ずつ作製し, 供試体底面の平面度と圧縮強 度を確認することとした。

使用材料と各調合での材料の組合せを表 5 および表 6 に, 調合を 表 7 に示寸。使用材料の組合せや調合は，実際に使われている調合 例をもとに定めている。2. 3 の実験と同様に, いずれの供試体の作 製にもスランプフロー600 $\mathrm{mm}$ 以上の高流動コンクリートを使用し, 供 試体の底面側の載荷面に気泡などが残らないようにしている。コン クリートは, 容量 $1.5 \mathrm{~m}^{3}$ の強制二軸式ミキサで練混ぜた。練混ぜ量 は $0.8 \mathrm{~m}^{3}$ を基本としたが, 結合材計量器の容量の限界から, 調合C11 のみは $0.7 \mathrm{~m}^{3}$ とした。なお, 練混ぜたコンクリートの均質性を確認 するため, 無作為に採取した 18 個の $\Phi 100 \times 200 \mathrm{~mm}$ 供試体を標準養生 し, 材齢 28 日および材齢 91 日に上下の載荷面を研磨して圧縮強度 試験を行った。結果を表 8 に示す。試験值のばらつきはまったく無 い訳ではないが，変動係数から考えれば，製造したコンクリートは 概ね均質に練り混ぜることができたと考えられる。

実験に用いる各調合 48 個（計 240 個）の供試体は, 同一の屋内で 10 ケ月間封かん養生した後に脱型し, 打込み側の載荷面のみを平面 度が JIS A 1132 の許容範囲 $(0.05 \mathrm{~mm})$ に入るように研磨した。その 後, 型枠底面側の載荷面の平面度を測定し, 圧縮強度試験を行った。 なお，いずれの供試体も，載荷面と側面の垂直度は，JIS A 1132 の 範囲に入っていた。

圧縮強度試験の結果について, 供試体底面側の載荷面の平面度で 整理した結果を図 7 に示す。本来，この試験では打込み側の載荷面 の平面度を $0 \mathrm{~mm}$ とすることが理想であるが，そのような精度で研磨 することはほぼ不可能である。そこで, 試験結果の考察は, 48 個と いう多数の供試体による試験結果の全体像を回帰線に置き換えるこ とで行うこととした。図 7 に示すように, データ的にはばらつきが あるものの，いずれのコンクリートも回帰線の傾きは負となってお り, 底面側の載荷面の平面度が大きく（悪く）なると, 強度が低下 する傾向がみられた。

図 7 の回帰線をもとに, 各調合の平面度 $0.05 \mathrm{~mm}, 0.10 \mathrm{~mm}$ および $0.20 \mathrm{~mm}$ における仮の圧縮強度（以下, 仮想圧縮強度と称寸る）を求 めた結果を表 9 に示す。

表 9 より，JIS A 1132 における平面度の許容限界となる平面度 $0.05 \mathrm{~mm}$ での仮想圧縮強度に対し, 平面度 $0.10 \mathrm{~mm}$ および $0.20 \mathrm{~mm}$ での
表 5 使用材料

\begin{tabular}{|c|c|c|c|}
\hline 種類 & 記号 & 名称 & 備考 \\
\hline \multirow{3}{*}{ 結合材 } & B11 & 高強度用結合材* & 密度 $2.99 \mathrm{~g} / \mathrm{cm}^{3}$ \\
\hline & B12 & $\begin{array}{l}\text { 普通ポルトランドセメト: } \\
\text { 高強度用混和材 } * *=8: 2\end{array}$ & 密度 $3.06 \mathrm{~g} / \mathrm{cm}^{3}$ \\
\hline & B13 & 中庸熱ポルトランドセメント & 密度 $3.21 \mathrm{~g} / \mathrm{cm}^{3}$ \\
\hline \multirow{3}{*}{ 細骨材 } & S11 & 安山岩系砕砂 & $\begin{array}{l}\text { 表乾密度 } 2.62 \mathrm{~g} / \mathrm{cm}^{3} \\
\text { 吸水率 } 2.95 \%\end{array}$ \\
\hline & S12 & 石灰岩系砕砂 & $\begin{array}{l}\text { 表乾密度 } 2.68 \mathrm{~g} / \mathrm{cm}^{3} \\
\text { 吸水率 } 1.89 \%\end{array}$ \\
\hline & S13 & 天然砂 & $\begin{array}{l}\text { 表乾密度 } 2.60 \mathrm{~g} / \mathrm{cm}^{3} \\
\text { 吸水率 } 1.27 \%\end{array}$ \\
\hline \multirow{2}{*}{ 粗骨材 } & G11 & 安山岩系砕石 & $\begin{array}{l}\text { 表乾密度 } 2.62 \mathrm{~g} / \mathrm{cm}^{3} \\
\text { 吸水率 } 2.28 \%\end{array}$ \\
\hline & G12 & 石灰岩系砕石 & $\begin{array}{l}\text { 表乾密度 } 2.72 \mathrm{~g} / \mathrm{cm}^{3} \\
\text { 吸水率 } 0.84 \%\end{array}$ \\
\hline
\end{tabular}

*普通ポ゙トランドセメト：スラグせっこう系混和材 12 ）：沙力ューム＝7:2:1

**スラグせっこう系混和材 $12 ） ：$ 沙力ューム $=2: 1$

表 6 使用材料の組合せ

\begin{tabular}{c|c|c|c|c}
\hline 調合名 & $\begin{array}{c}\text { W/B } \\
(\%)\end{array}$ & 結合材 & 細骨材 & 粗骨材 \\
\hline \hline $\mathrm{C} 11$ & 15 & $\mathrm{~B} 11$ & $\mathrm{~S} 11$ & $\mathrm{G} 11$ \\
\hline $\mathrm{C} 12$ & 21 & $\mathrm{~B} 11$ & $\mathrm{~S} 12: \mathrm{S} 13=5: 5$ & $\mathrm{G} 12$ \\
\hline $\mathrm{C} 13$ & 19 & $\mathrm{~B} 12$ & $\mathrm{~S} 12: \mathrm{S} 13=5: 5$ & $\mathrm{G} 12$ \\
\hline $\mathrm{C} 14$ & 27 & $\mathrm{~B} 12$ & $\mathrm{~S} 12: \mathrm{S} 13=5: 5$ & $\mathrm{G} 12$ \\
\hline $\mathrm{C} 15$ & 24 & $\mathrm{~B} 13$ & $\mathrm{~S} 12: \mathrm{S} 13=5: 5$ & $\mathrm{G} 12$ \\
\hline
\end{tabular}

表 7 コンクリートの調合

\begin{tabular}{c|c|c|c|c|c}
\hline \multirow{2}{*}{ 調合名 } & \multirow{2}{*}{$\begin{array}{c}\text { W/B } \\
\text { (\%) }\end{array}$} & \multicolumn{4}{|c}{ 単位量 $\left(\mathrm{kg} / \mathrm{m}^{3}\right)$} \\
\cline { 3 - 6 } & & 結合材 & 水 & 細骨材 & 粗骨材 \\
\hline \hline $\mathrm{C} 11$ & 15 & 1067 & 160 & 409 & 817 \\
\hline $\mathrm{C} 12$ & 21 & 738 & 155 & 658 & 895 \\
\hline $\mathrm{C} 13$ & 19 & 816 & 155 & 600 & 895 \\
\hline $\mathrm{C} 14$ & 27 & 574 & 155 & 810 & 895 \\
\hline $\mathrm{C} 15$ & 24 & 667 & 160 & 718 & 914 \\
\hline
\end{tabular}

表 8 製造したコンクリートの圧縮強度試験結果（9個）

\begin{tabular}{|c|c|c|c|c|c|c|}
\hline \multirow[b]{2}{*}{$\begin{array}{c}\text { 調合 } \\
\text { 名 }\end{array}$} & \multicolumn{3}{|c|}{ 材齢 28 日 } & \multicolumn{3}{|c|}{ 材齢 91 日 } \\
\hline & $\begin{array}{c}\text { 平均 } \\
\text { 標準養生 } \\
\text { 圧縮強度 } \\
\mathrm{N} / \mathrm{mm}^{2}\end{array}$ & $\begin{array}{l}\text { 標準 } \\
\text { 偏差 } \\
\mathrm{N} / \mathrm{mm}^{2}\end{array}$ & $\begin{array}{c}\text { 変動 } \\
\text { 係数 } \\
\%\end{array}$ & $\begin{array}{c}\text { 平均 } \\
\text { 標準養生 } \\
\text { 圧縮强度 } \\
\mathrm{N} / \mathrm{mm}^{2}\end{array}$ & $\begin{array}{l}\text { 標隻 } \\
\text { 偏差 } \\
\mathrm{N} / \mathrm{mm}^{2}\end{array}$ & $\begin{array}{c}\text { 変動 } \\
\text { 係数 } \\
\%\end{array}$ \\
\hline $\mathrm{C} 11$ & 141 & 2.1 & 1.5 & 156 & 4.2 & 2.7 \\
\hline $\mathrm{C} 12$ & 126 & 2.4 & 1.9 & 138 & 3.8 & 2.8 \\
\hline $\mathrm{C} 13$ & 111 & 3.0 & 2.7 & 123 & 3.5 & 2.8 \\
\hline $\mathrm{C} 14$ & 127 & 2.1 & 1.6 & 142 & 2.9 & 2.1 \\
\hline $\mathrm{C} 15$ & 113 & 1.7 & 1.5 & 124 & 1.6 & 1.3 \\
\hline
\end{tabular}




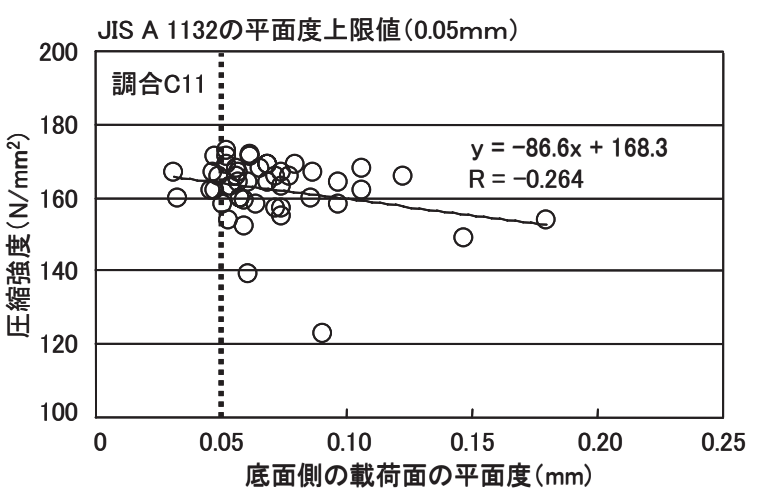

表 9 各コンクリートの平面度に対応する仮想圧縮強度

\begin{tabular}{c|c|c|c|c|c}
\hline \multirow{2}{*}{ 調合名 } & \multirow{2}{*}{ 図一7 の回帰式 } & \multirow{2}{*}{$\begin{array}{c}\text { 相関 } \\
\text { 係数 }\end{array}$} & \multicolumn{3}{|c}{ 各平面度での仮想圧縮強度 $\left(\mathrm{N} / \mathrm{mm}^{2}\right)$} \\
\cline { 5 - 7 } & & $\mathrm{R}$ & 平面度 & 平面度 & 平面度 \\
& & & $0.05 \mathrm{~mm}$ & $0.10 \mathrm{~mm}$ & $0.20 \mathrm{~mm}$ \\
\hline \hline $\mathrm{C} 11$ & $\mathrm{Y}=-86.6 \mathrm{X}+168.3$ & -0.2641 & 164 & 160 & 151 \\
\hline $\mathrm{C} 12$ & $\mathrm{Y}=-51.3 \mathrm{X}+151.5$ & -0.2773 & 149 & 146 & 141 \\
\hline $\mathrm{C} 13$ & $\mathrm{Y}=-32.3 \mathrm{X}+143.3$ & -0.2442 & 142 & 140 & 137 \\
\hline $\mathrm{C} 14$ & $\mathrm{Y}=-9.5 \mathrm{X}+131.6$ & -0.0843 & 131 & 131 & 130 \\
\hline $\mathrm{C} 15$ & $\mathrm{Y}=-50.8 \mathrm{X}+134.6$ & -0.4397 & 132 & 130 & 124 \\
\hline
\end{tabular}
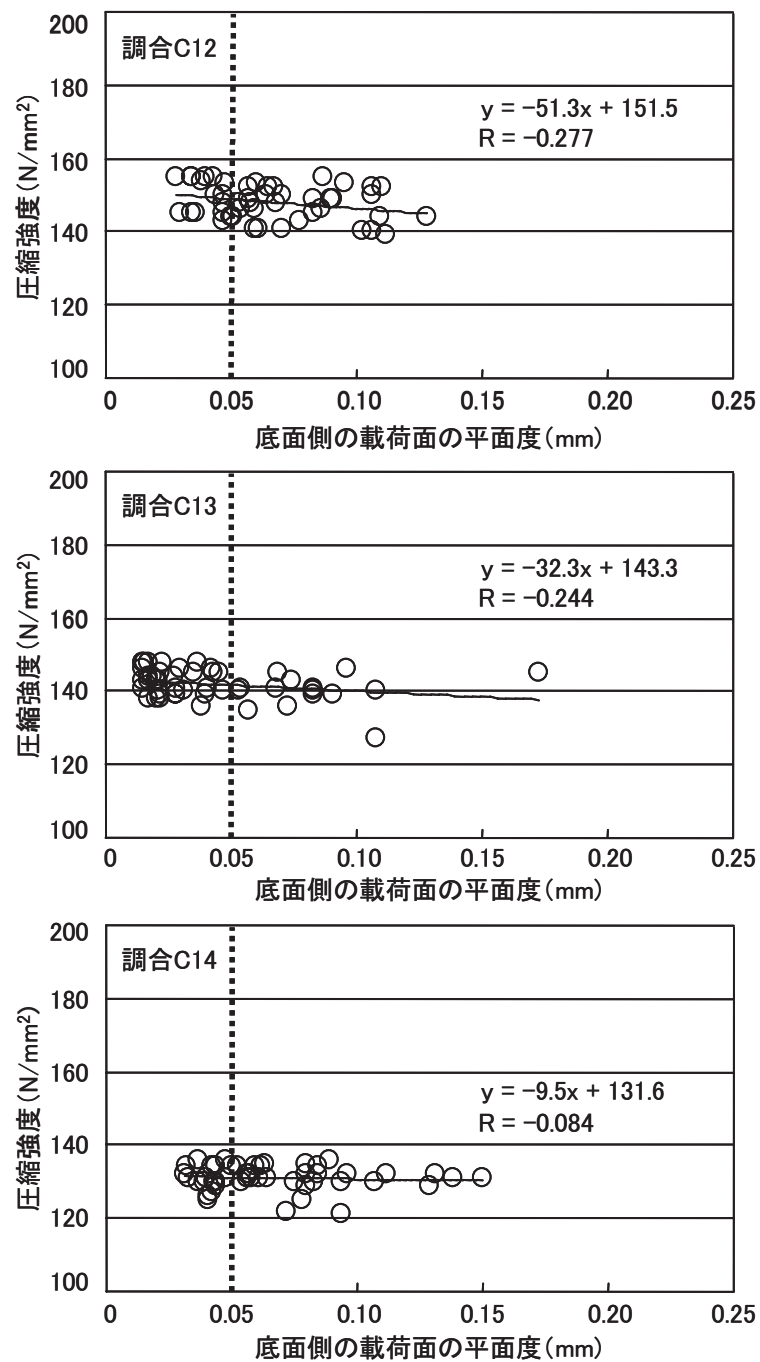

表 10 平面度 $0.05 \mathrm{~mm}$ に対する仮想圧縮強度比

\begin{tabular}{c|c|c|c}
\hline \multirow{2}{*}{ 調合名 } & \multicolumn{3}{|c}{ 平面度 $0.05 \mathrm{~mm}$ に対する仮想圧縮強度比 } \\
\cline { 2 - 4 } & $\begin{array}{c}\text { 平面度 } \\
0.05 \mathrm{~mm}\end{array}$ & $\begin{array}{c}\text { 平面度 } \\
0.10 \mathrm{~mm}\end{array}$ & $\begin{array}{c}\text { 平面度 } \\
0.20 \mathrm{~mm}\end{array}$ \\
\hline \hline $\mathrm{C} 11$ & 100 & 97.6 & 92.0 \\
\hline $\mathrm{C} 12$ & 100 & 98.0 & 94.6 \\
\hline $\mathrm{C} 13$ & 100 & 98.6 & 96.5 \\
\hline $\mathrm{C} 14$ & 100 & 100 & 99.2 \\
\hline $\mathrm{C} 15$ & 100 & 98.5 & 93.9 \\
\hline
\end{tabular}

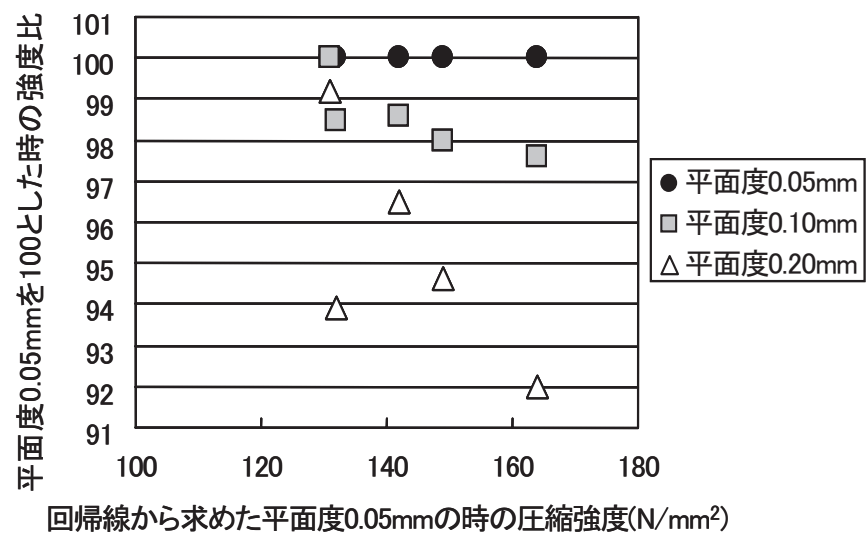

図 8 圧縮強度と平面度が強度比に及ぼす影響の関係

仮想圧縮強度は，大きいもので $10 \mathrm{~N} / \mathrm{mm}^{2}$ 以上低下していることがわ かる。

次に, 表 9 をもとに, 平面度 $0.05 \mathrm{~mm}$ での仮想圧縮強度を 100 とし た場合の平面度 $0.10 \mathrm{~mm}$ おび $0.20 \mathrm{~mm}$ での仮想圧縮強度の強度比を 計算したものを表 10 に示寸。これより, 平面度 $0.20 \mathrm{~mm}$ での強度比 は, 低下率が大きい場合には 90 近くになることがわかる。圧縮強度 10〜 $40 \mathrm{~N} / \mathrm{mm}^{2}$ 程度を対象とした丸安の論文 ${ }^{4)}$ によれば，平面度 $\pm 0 \mathrm{~mm}$ に対して, 平面度 $0.10 \mathrm{~mm}$ では圧縮強度は $8 \sim 10 \%$ 程度低くなると報 告されている。平面度 $0.05 \mathrm{~mm}$ を 100 とした本論とは少し整理の仕方 が異なるが，超高強度領域でも一般的な強度領域に比べて極端に大 きな強度低下が起こるわけではないと考えられる。ただし，この検 討結果は, 図 7 のデータが直線的に分布すると仮定して外挿された 範囲も含めて導いた結果であるため, 今後, より多くのデータを蓄 積し，検証していく必要がある。 
表 9 および表 10 の整理は, 各調合の強度低下を把握するのには適 しているが, 全体的な傾向はつかみ辛い。そこで, 表 9 に示した平 面度 $0.05 \mathrm{~mm}$ での仮想圧縮強度を横軸に, 表 10 に示した強度比を縌 軸にして, 結果を整理した。結果を平面度ごとに分類して

図 8 に示寸。図 8 より, 今回の実験範囲では, 平面度 $0.05 \mathrm{~mm}$ での仮 想圧縮強度が高くなるにつれ, 同一平面度での強度低下が顕著とな る傾向にあったことがわかる。圧縮強度 $10 \sim 30 \mathrm{~N} / \mathrm{mm}^{2}$ 程度を対象と した児玉の論文 ${ }^{9)}$ によば，コンクリートの圧縮強度が高くなるほ ど平面度が圧縮強度に及ぼす影響が大きくなることが報告されてい る。この知見は図 8 の検討結果と符合しており, 超高強度領域でも 一般的な強度に近い傾向があるものと考えられる。ただし, 図 8 は, 平面度 $0.05 \mathrm{~mm}$ での仮想圧縮強度が $100 \sim 120 \mathrm{~N} / \mathrm{mm}^{2}$ 程度を超えない限 り, 平面度 $0.20 \mathrm{~mm}$ 以内での強度低下は生じないとも読み取れる傾向 であるため, 今後, より多くのデータを追加し, 妥当な回帰線が提 案できるように精度を向上させることが望ましいと考えられた。ま た，筆者らが過去に報告した文献 ${ }^{1)}$ の結果でも見られたように，い くつかの供試体の結果に注目すれば，載荷面の平面度が大きい（悪 い）にも関わらず, 平面度が $0.05 \mathrm{~mm}$ 以内の供試体とほぼ同等の圧縮 強度が得られた供試体も存在することがわかる。これは, 今回の整 理では平面度 $0.05 \mathrm{~mm}$ 以内に研磨した打込夕面（研磨面）の平面度の 影響を無視しているが，実際には打込み面（研磨面）の平面度も0 に近いほうが強度的には高くなると考えられること, 表 8 に示した ように両載荷面を平面度 $0.05 \mathrm{~mm}$ 以内に研磨した供試体の圧縮強度 試験結果でも $1 \sim 4 \mathrm{~N} / \mathrm{mm}^{2}$ 程度の標準偏差を持つことなどの影響と考 えられる。特に, 後者の影響は実験的に完全に取り除くことは難し いと考えられるため, 図 8 の精度向上には本論よりもより多くの実 験データが不可欠と考えられる。

\section{4.まとめ}

本研究では, 圧縮強度 $100 \mathrm{~N} / \mathrm{mm}^{2}$ を超える高強度コンクリート供 試体の載荷面の処理作業における留意点を明確にすることを目的と し, 供試体の載荷面の平面度と圧縮強度試験で得られる結果の関係 について一連の実験を行った。以下に，結論を示す。

（1）供試体の平面度測定に関する基本的な検討を行った結果, JIS A 5308 の附属書 5 に示される平面度測定装置を用いて 17 点程度の測定を行えば，概放その供試体の平面度が求められる と考えられた。

（2）供試体の平面度は材齢の経過によって変化した。したがって, 供試体の載荷面の整形時期は, 圧縮強度試験の試験材齢とあま り離れていないことが望ましい。なお，検定された型枠を用い て供試体の平面度測定を省略する場合や，載荷面の研磨から圧 縮強度試験までの期間が長い場合には，供試体底面や研磨した
載荷面の平面度が JIS A 1132 の許容範囲 $(0.05 \mathrm{~mm})$ を十分に下 回っていることを確認するのが良いと考えられた。

（3）今回使用した軽量型枠で作製された $\Phi 100 \times 200 \mathrm{~mm}$ 供試体底面 の平面度は, 約 3 面に 1 面が JIS A 1132 の許容範囲を満たす 程度であり，寸べてが許容範囲内には収まらなかった。ただし， このような精度で成形された供試体であっても，研磨を行えば， JIS A 1132 の許容範囲内に端面精度を整形することができた。

（4）圧縮強度 $120 \sim 180 \mathrm{~N} / \mathrm{mm}^{2}$ 程度の範囲にある 5 種類の高強度コン クリートで実施した今回の実験では, 型枠底面側の載荷面の平 面度が大きく（悪く）なるにつれ，圧縮強度試験結果は低下寸 る傾向が見られた。

（5）圧縮強度 $120 \sim 180 \mathrm{~N} / \mathrm{mm}^{2}$ 程度の範囲にある 5 種類の高強度コン クリートで実施した今回の実験では，実験で得られた回帰式か ら求めた平面度 $0.05 \mathrm{~mm}$ での仮想圧縮強度が高くなるにつれ, 平 面度が大きくなった（悪くなった）場合の強度低下が顕著とな る傾向にあった。ただし，この点についてはデータ数も十分で はなく, 今後より多くのデータを追加し, 妥当な回帰線が提案 できるように精度を向上させることが望ましいと考えられた。

\section{参考文献}

1）小山善行，早川光敬，陣内浩，今西正尚：超高強度コンクリートの圧縮強 度に及ぼす端面処理の影響, 日本コンクリート工学協会年次論文集 Vol. 29, No. 1, pp. 519-524, 2007

2）小野山貫造，野口貴文，友澤史紀 : 高強度コンクリートの圧縮強度試験方 法の標潐化に関する研究（その 7 端面処理方法の影響），日本建築学会 大会学術講演梗概集 A，pp.877-878，1991.9

3）鈴木澄江, 桝田佳寛, 野口貴文, 陣内 浩 : 高強度コンクリートの圧縮強 度の確率分布に及ぼす試験機及び供試体の影響, 日本建築学会構造系論文 集，No. 598，pp. 1-6，2005.12

4）丸安隆和, 水野俊一: コンクリートの圧縮強度試験に用いる型枠の底板の 不整が圧縮強度に及ぼす影響について，土木技研，pp. 10-13，1954.4

5）コンクリート専門委員会：コンクリートの圧縮強度試験におけるキャッピ ング材料およびキャッピング方法，セメント・コンクリート，No. 309, pp. $2-7, \quad 1972.11$

6）水野俊一, 笠原 正：コンクリート供試体のキャッピング面の不整につい て，セメント・コンクリート，No. 163，pp.11-12，1960.9

7）青木完雄, 中村静麿: コンクリートのキャッピング方法と圧縮強度, セメ ント技術年報，No. 15，pp. 223-228，1961

8）吉本 彰, 長谷川博: コンクリートの破壊におよぼすキャッピング, セメ ント技術年報, No. 36, pp. 187-190, 1972

9）児玉武三，鵜飼光夫，小林 充: コンクリートの型わくの誤差が強さに及 ぼす影響について，セメント技術年報，XI，pp. 297-302，1957

10）奥田 徹：コンクリートの試験方法 3. キャッピングの方法，コンクリ ート・ジャーナル, Vol.10, No.12, pp. 46-56, 1972.12

11）日本建築学会：建築工事標準仕様書・同解説 JASS5 鉄笳コンクリート工 事 付 15. JASS5 T-606 : 2005 簡易断熱養生供試体による構造体コンク リート強度の推定方法, pp. 705-706, 2009.2

12）日本建築学会 : 建築工事標準仕様書・同解説 JASS5 鉄筋コンクリート工 事 付 18. JASS5 M-701：2005 高強度コンクリート用セメントの品質 基準 附属書 3， p. 719，2009.2

（2009年 6 月 3 日原稿受理，2009年11月19日採用決定） 